\title{
Germination test of Eucalyptus phaeotricha seeds
}

\author{
Carlos E. Affonso ${ }^{1}$, Givanildo Z. da Silva ${ }^{2}$, Tatiane S. Jeromini ${ }^{1}$ \& Cibele C. Martins ${ }^{1}$ \\ ${ }^{1}$ Universidade Estadual Paulista/Faculdade de Ciências Agrárias e Veterinárias/Campus de Jaboticabal. Jaboticabal, SP. E-mail: ceaffonso@outlook.com \\ - ORCID: 0000-0002-8898-1637; tatiane_jeromini@hotmail.com (Corresponding author) - ORCID: 0000-0003-0810-3111; cibele.chalita@unesp.br - \\ ORCID: 0000-0002-1720-9252 \\ ${ }^{2}$ Universidade Federal de Goiás/Regional de Jataí. Jataí, GO. E-mail: givanildozildo@hotmail.com - ORCID: 0000-0002-6380-1599
}

\author{
Key words: \\ temperature \\ substrate \\ moistening \\ Eucalyptus tindaliae
}

\begin{abstract}
A B S T R A C T
The rules for seed analysis do not have recommendations for conducting the germination test of Eucalyptus phaeotricha seeds. Thus, the aim of this study was to determine the best substrate, temperature, conduction time, and substrate moistening level for the germination test of E. phaeotricha seeds. First count of germination, germination, germination speed index and mean time of germination were evaluated. The first experiment was carried out in a completely randomized design, in a factorial scheme $(6 \times 2)$, corresponding to six temperature regimes $\left(15,20,25,30,35^{\circ} \mathrm{C}\right.$ and $\left.20-30{ }^{\circ} \mathrm{C}\right)$ and two substrates (paper and sand) with four replicates, and the means were compared by Tukey test at 0.05 probability level. In the second experiment, the germination test was installed with the most favorable substrate and temperature identified in the previous step, evaluating substrate moistening levels equivalent to $1.0,1.5,2.0,2.5$ and 3.0 times the dry weight of the substrate; due to the quantitative nature of the treatments, the data were subjected to regression analysis and curve fitting. The germination test of E. phaeotricha seeds should be conducted at $30^{\circ} \mathrm{C}$ on paper, moistened with a water volume of 2.2 times the dry weight of the paper, with initial and final counts at 6 and 14 days after sowing, respectively.
\end{abstract}

\author{
Palavras-chave: \\ temperatura \\ substrato \\ umedecimento \\ Eucalyptus tindaliae
}

\section{Teste de germinação de sementes de Eucalyptus phaeotricha}

\section{R E S U M O}

As regras de análise de sementes não possuem recomendações para a condução do teste de germinação de sementes de Eucalyptus phaeotricha. Assim, o objetivo da pesquisa foi determinar o melhor substrato, temperatura, tempo de condução e umedecimento do substrato para o teste de germinação de sementes desta espécie. Foram avaliados a primeira contagem de germinação, germinação, o índice de velocidade de germinação e o tempo médio de germinação. $\mathrm{O}$ primeiro experimento foi realizado em delineamento inteiramente casualizado, com quatro repetições em esquema fatorial $6 \times 2$, sendo seis os regimes de temperatura $\left(15,20,25,30,35^{\circ} \mathrm{C}\right.$ e $\left.20-30^{\circ} \mathrm{C}\right)$ e dois substratos (papel e areia). As médias foram comparadas pelo teste de Tukey a $5 \%$ de probabilidade. No segundo experimento o teste de germinação foi instalado com o substrato e a temperatura mais favoráveis identificados na etapa anterior e avaliou-se o umedecimento com 1,0; 1,5;2,0; 2,5 e 3,0 vezes a massa seca do substrato em água. Os dados foram submetidos à análise de regressão e ajuste de curvas. O teste de germinação de sementes de E. phaeotricha deve ser realizado a $30^{\circ} \mathrm{C}$ sobre papel e com umedecimento de 2,2 vezes a massa do papel seco em água e contagem inicial e final aos seis e 14 dias após a semeadura, respectivamente.
\end{abstract}




\section{INTRODUCTION}

Eucalyptus phaeotricha Blakely \& Mckie is used for commercial reforestation and wood production (Lorenzi, 2003). Eucalyptus spp. propagation by seeds is viable and adopted by small nursery owners to produce seedlings (Cetnarski Filho \& Carvalho, 2009). Seed germination is used to calculate sowing rate, evaluate the physiological quality of a lot, and establish criteria for commercialization (Martins et al., 2008; Tomaz et al., 2016).

The Rules for Seed Analysis - RAS (Brasil, 2009) do not have any norms for the germination test of E. phaeotricha but provide descriptions of procedures for 47 other species of the same genus. The temperature recommended for the germination test of E. elata, E. fastigiata, E. macrorhyncha, E. muelleriana, E. pauciflora, E. polybractea and E. regnans seeds was $15^{\circ} \mathrm{C}$, and for E. deglupta, E. largiflorens and E. rudis it was $35^{\circ} \mathrm{C}$ (Brasil, 2009). Only one regime of alternated temperature was found, $20-30^{\circ} \mathrm{C}$, for E. grandis. Regarding the substrates, paper and sand are recommended (Brasil, 2009, 2013). These data demonstrate the differences between species of the same genus and it is necessary to conduct tests for the other species.

For E. dunnii seeds, Cetnarski Filho \& Carvalho (2009) concluded that the substrates sand or paper and temperature of $20^{\circ} \mathrm{C}$ provided the most favorable conditions for the germination test. For seeds of forest species and major crops such as soybean, corn, cotton, forage species, among others, the recommendations of substrate moistening levels in the test are 2 to 3 times its dry weight for blotter paper and 50 to $60 \%$ of its water retention capacity for sand (Varela et al., 2005; Brasil, 2009, 2013; Gonçalves et al., 2015).

Thus, the objective was to determine the substrate, temperature, substrate moistening level and time of count for the germination test of E. phaeotricha seeds.

\section{Material AND Methods}

E. phaeotricha seeds used in the study were harvested in the plot A24T88 of the Forestry Science and Research Institute (IPEF) in the municipality of Anhembi, SP, and sent to the Seed Analysis Laboratory of the Plant Sciences Department of the Faculty of Agrarian and Veterinary Sciences of the UNESP, Campus of Jaboticabal, SP, Brazil.

A first experiment evaluated the effect of temperatures and substrates on seed germination through the following tests:

Germination: Installed with four subsamples of $0.25 \mathrm{~g}$ of seeds, following the recommendation of Brasil (2009) for other species of the same subgenus of E. phaeotricha: Monocalyptus. Sowing was performed on blotter paper and sand, autoclaved and kept in transparent plastic boxes (11.0 $\mathrm{x} 11.0 \times 3.5 \mathrm{~cm}$ ), and the substrates were moistened with distilled water using a volume equivalent to 2.5 times the dry weight for the paper and $60 \%$ of the retention capacity for sand (Brasil, 2009).

The tests were conducted at constant temperatures of $15,20,25,30,35$ and alternated temperature of $20-30{ }^{\circ} \mathrm{C}$, under 8 -h photoperiod. Counts were daily carried out until the stabilization of germination, computing at the end of the test the number of normal seedlings, i.e., those which had shoots and radicle (Brasil, 2009). Normal and abnormal seedlings identified at the end of the germination test were photographed and their characteristics were described to serve as an image bank and allow the recognition by laboratory technicians.

First count: Conducted along with the germination test, by computing normal seedlings when the count reached $50 \%$ of the final germination (Tomaz et al., 2016).

Germination speed index: conducted simultaneously with the germination test by daily counts of normal seedlings until the end of the germination test (Maguire, 1962).

Mean time of germination: Calculated based on the daily count of normal seedlings until the final date of the germination test (Labouriau \& Valadares, 1976).

The experiment was conducted in completely randomized design in $6 \times 2$ factorial scheme (temperature regimes $\mathrm{x}$ types of substrate), with four replicates. Means were compared by Tukey test at 0.05 probability levels.

Upon defining the best temperature $\left(30^{\circ} \mathrm{C}\right)$ and substrate (paper) for the germination of E. phaeotricha seeds, a curve of germination was constructed to establish the date of first count and final count in the germination test.

After that, a second experiment was installed, on paper moistened with a water volumes equivalent to $1.0,1.5,2.0$, 2.5 and 3.0 times its weight and conducted at $30{ }^{\circ} \mathrm{C}$, under 8 -h photoperiod, to verify which is the ideal level of substrate moistening. This experiment evaluated germination and germination speed index, as previously described.

Due to the quantitative nature of the treatments in the second experiment, these data were subjected to regression analysis and curve fitting, estimating the points which led to optimization of the variables measured.

\section{Results AND Discussion}

The standard germination test ended at 28 days because from this date on no normal seedlings emerged in any treatment for three successive counts. There was no effect of the interaction between substrate and temperature or substrate alone on any of the variables analyzed (Table 1). Only temperature significantly influenced all parameters involved in the germinative process of E. phaeotricha seeds.

Therefore, it was possible to observe that the substrates sand and paper provided similar conditions for the germination of E. phaeotricha seeds. The similar performance of seeds in both

Table 1. Summary of analysis of variance of Eucalyptus phaeotricha seeds subjected to different substrates and temperatures

\begin{tabular}{|c|c|c|c|c|c|}
\hline \multirow{2}{*}{$\begin{array}{c}\text { Source } \\
\text { of variation }\end{array}$} & \multirow{2}{*}{ DF } & \multicolumn{4}{|c|}{ Mean square } \\
\hline & & Germination & GSI & MTG & First count \\
\hline Temperatures (T) & 5 & $406.59 * \star$ & $70.65^{\star}$ & $55.32 * *$ & $437.27^{\star \star}$ \\
\hline Substrates (S) & 1 & $46.02^{\mathrm{ns}}$ & $15.92^{\mathrm{ns}}$ & $0.19^{\text {ns }}$ & $4.69^{\text {ns }}$ \\
\hline $\mathrm{T} \times \mathrm{S}$ & 5 & $168.92^{\mathrm{ns}}$ & $9.28^{\text {ns }}$ & $0.79^{n s}$ & $52.74^{\mathrm{ns}}$ \\
\hline Residual & 7 & 80.02 & 7.07 & 0.34 & 25.83 \\
\hline CV (\%) & & 15.24 & 32.90 & 6.50 & 50.30 \\
\hline
\end{tabular}

GSI - Germination speed index ns; ${ }^{* *}$; MTG - Mean time of germination; *Not significant; Significant at 0.01 and 0.05 probability levels by $F$ test, respectively 
substrates confirmed the reports of Ferreira et al. (1992) about the high adaptability of this species to different environmental conditions. For E. delegatensis and E. elata, which belong to the same subgenus of the species studied (Monocalyptus), the RAS (Brasil, 2009) only recommend sowing on paper.

E. phaeotricha seeds showed maximum germination at 20$30^{\circ} \mathrm{C}$ and minimum germination at 20 and $35^{\circ} \mathrm{C}$. However, these values did not differ from those obtained at the other temperatures evaluated (Table 2). Maximum number of normal seedlings obtained under different temperature conditions may be an indication of high adaptive capacity of this species to the climate, thus increasing its chances of survival and establishment in the field (Guedes et al., 2010; Silva et al., 2017). This fact has also been observed for seeds of other forest species, such as Parkia platycephala Benth (Silva et al., 2017) and Amburana cearensis (Allemão) A. C. Smith (Guedes et al., 2010).

No significant differences were found between treatments with respect to number of abnormal seedlings, and there were no abnormal seedlings in the germination test conducted at temperatures of 25 and $30{ }^{\circ} \mathrm{C}$. However, some abnormalities were found in seedlings obtained at the other temperatures at the end of the germination test.

Seedlings should be evaluated according to the general principles indicated in RAS (Brasil, 2009), which provided a list of the types of abnormalities. Figure 1 presents the main types of abnormal seedlings of E. phaeotricha found in the germination test and also of a normal seedling (Figure 1E). The last one would be the seedling with well-developed shoots and roots.

According to the Normative Instructions for Forest Species, abnormal seedlings do not have development potential to originate normal plants under field conditions (Brasil, 2013). However, there are no figures in this publication to illustrate the

Table 2. Germination, first count, germination speed index and mean time of germination of $E$. phaeotricha seeds sown on paper and on sand, at different temperatures

\begin{tabular}{ccccc}
\hline $\begin{array}{c}\text { Temp. } \\
\left({ }^{\circ} \mathrm{C}\right)\end{array}$ & Germination ${ }^{\#}$ & First count ${ }^{\#}$ & $\begin{array}{c}\text { GSI } \\
\text { (days) }\end{array}$ & MTG \\
15 & $55 \mathrm{ab}$ & $0 \mathrm{c}$ & $4.73 \mathrm{c}$ & $13 \mathrm{~d}$ \\
20 & $51 \mathrm{~b}$ & $2 \mathrm{c}$ & $5.17 \mathrm{c}$ & $11 \mathrm{c}$ \\
25 & $65 \mathrm{ab}$ & $34 \mathrm{ab}$ & $9.65 \mathrm{ab}$ & $7 \mathrm{a}$ \\
30 & $64 \mathrm{ab}$ & $46 \mathrm{a}$ & $12.75 \mathrm{a}$ & $7 \mathrm{a}$ \\
35 & $51 \mathrm{~b}$ & $24 \mathrm{~b}$ & $7.83 \mathrm{bc}$ & $7 \mathrm{a}$ \\
$20-30$ & $67 \mathrm{a}$ & $23 \mathrm{~b}$ & $8.36 \mathrm{bc}$ & $8 \mathrm{~b}$ \\
\hline
\end{tabular}

\# Normal seedlings/0.25 g of seeds; GSI - Germination speed index; MTG - Mean time of germination; Means followed by the same lowercase letter in the column do not differ by Tukey test at 0.05 probability level

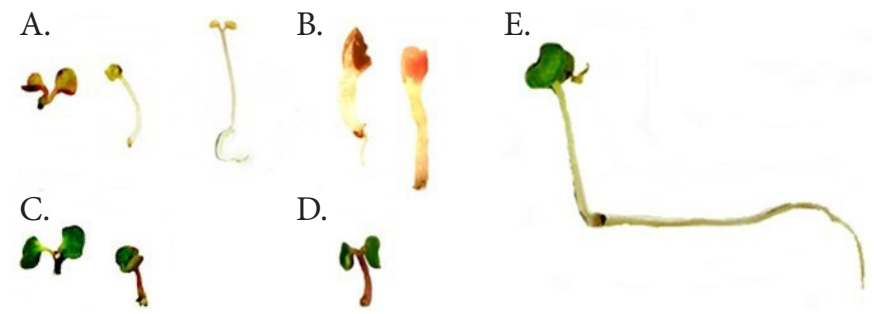

Figure 1. Abnormal seedlings of Eucalyptus phaeotricha compared with the normal one. Abnormal seedlings obtained at temperatures of $15^{\circ} \mathrm{C}(\mathrm{A}), 35^{\circ} \mathrm{C}(\mathrm{B}), 20^{\circ} \mathrm{C}$ (C), alternated of $20-30{ }^{\circ} \mathrm{C}(\mathrm{D})$ and normal seedling (E) abnormalities of Eucalyptus spp. seedlings. The abnormalities observed in E. phaeotricha seedlings were: chlorotic leaves (Figure 1A), cotyledon with evidence of damages to the terminal bud (Figure 1B), absence of apical bud in the epicotyl (Figure 1C), absent or poorly developed primary root (Figure 1D). These abnormalities were consistent with those described by Brasil (2009) for dicotyledonous species.

According to the effect of temperature on germination speed evaluated by the test of first count and germination speed index, the temperatures of 25 and $30^{\circ} \mathrm{C}$ were the most favorable to the process. These temperatures were also the most favorable to the germination speed of E. dunnii seeds (Cetnarski Filho \& Carvalho, 2009).

The lowest values of the first count test were found in seeds kept at 15 and $20^{\circ} \mathrm{C}$. Intermediate values of germination on the date of first count were found at 35 and $20-30{ }^{\circ} \mathrm{C}$, although these did not differ from that obtained at $25^{\circ} \mathrm{C}$.

According to the results of the germination speed index, the temperatures of $15,20,35$ and $20-30{ }^{\circ} \mathrm{C}$ were the most harmful ones, although the last two, 35 and $20-30^{\circ} \mathrm{C}$, did not differ from $25^{\circ} \mathrm{C}$ regarding this parameter. Higher or lower than optimal temperatures tend to reduce the speed of the germination process, exposing the seeds to adverse climate factors for a longer period (Barros et al., 2017). This phenomenon could also be observed in seeds of other species such as Dalbergia cearensis (Nogueira et al., 2014), Inga laurina (Barrozo et al., 2014) and Senegalia tenuifolia (Araújo et al., 2016).

Germination speed, measured by the mean time of germination, revealed that the time of seven days was sufficient for the seeds germinated at temperature of $30^{\circ} \mathrm{C}$ to express their maximum germination capacity and such mean time of germination was not influenced by the substrates.

The second experiment was conducted at $30{ }^{\circ} \mathrm{C}$ because this temperature led to higher germination percentage within the shortest time. Sowing on paper was selected because this substrate did not differ from sand and had greater practicality of installation, handling and disposal of the test (Brasil, 2009).

The first count should be performed on the sixth day after sowing because on this date germination was approximately $50 \%$ of that obtained at the end of the test, as recommended by Tomaz et al. (2016). Therefore, the germination test with E. phaeotricha seeds conducted on paper at $30{ }^{\circ} \mathrm{C}$ could be ended at 14 days after sowing, when the production of normal seedlings stabilized for three consecutive counts with the same value (Figure 2 ).

The time of 16 days to conclude the germination test with E. phaeotricha is similar to the recommendation of 14 days for other species of Eucalyptus, such as E. camaldulensis, E. cinereal and E. tereticornis. However, the date of the first count, at 6 days, is later than that recommended for these and other species of the same genus; at 3 days for E. camaldulensis, E. cinerea and E. tereticornis and at 5 days for E. grandis and E. radiata (Brasil, 2009, 2013).

Based on the effect of substrate moistening on E. phaeotricha germination, it was observed that the obtained data fitted to a quadratic equation for germination and for germination speed index, with significant effect of the moistening level (Table 3). 


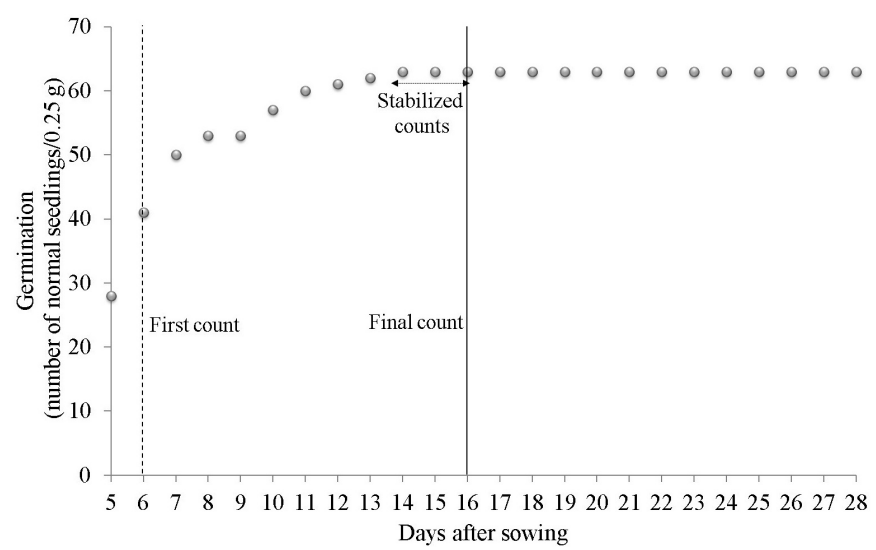

Figure 2. Daily germination of Eucalyptus phaeotricha seeds sown on paper at $30^{\circ} \mathrm{C}$

Table 3. Summary of the analysis of variance of Eucalyptus phaeotricha seeds subjected to different levels of moistening of the substrate paper

\begin{tabular}{lccc}
\hline \multirow{2}{*}{ Source of variation } & \multirow{2}{*}{ DF } & \multicolumn{2}{c}{ Mean square } \\
\cline { 3 - 4 } Moistening levels & 5 & Germination & GSI \\
\hline Quadratic equation fit & 1 & $2,250.40^{\star \star}$ & $11.16^{\star \star}$ \\
Residual & 15 & 159.85 & $20.91^{\star *}$ \\
CV (\%) & & 24.91 & 2.28 \\
\hline
\end{tabular}

GSI - Germination speed index ** Significant at 0.01 probability level by $F$ test

For the second test conducted at $30^{\circ} \mathrm{C}$, maximum values of germination and germination speed index were found when sowing was performed on paper moistened with 2.21 and 2.24 times its dry weight, respectively (Figure 3 ).

For E. phaeotricha seeds, substrate moistening at levels lower than 2.0 or higher than 2.5 times the dry weight of the paper led to reduction in germination, due to the lower production of normal seedlings and germination speed. Probably, at moistening levels lower than 2.0 times the dry weight of the paper, water availability was insufficient to trigger the germination process, as observed in seeds of Melaleuca quinquenervia and Bixa orellana L. (Martins et al., 2011; Sousa et al., 2015). At moistening levels higher than 2.5 times, the excess water in the substrate must have hindered seed germination due to the lower aeration.

This result may vary for the different species of Eucalyptus because these seeds have different levels of tolerance to water stress conditions due to the evolutive adaptation of the sites of origin (Martins et al., 2014).

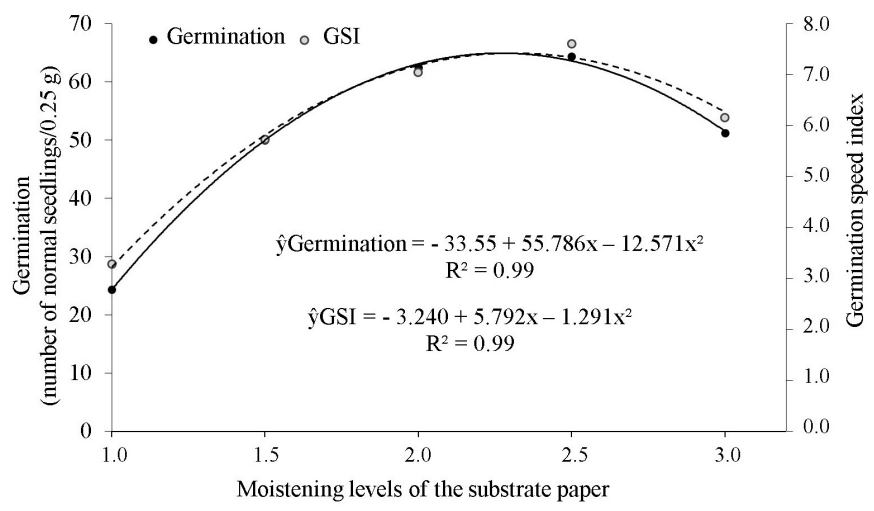

Figure 3. Germination and germination speed index of $E$. phaeotricha seeds germinated at $30^{\circ} \mathrm{C}$ on paper moistened with 1.0, 1.5, 2.0, 2.5 and 3.0 its dry weight
Given the importance of using the right amount of water to moisten the substrate, the Rules for Seed Analysis (Brasil, 2009) established the addition of a volume between 2.0 and 3.0 times its dry weight.

E. phaeotricha seeds required moistening level close to 2.5 times the paper dry weight for maximum germination. When germinated under higher levels of moistening, the seeds had a reduction in final germination and germination speed. Small seeds are sensitive to the excess of water in the substrate and, for most species with small seeds, the recommendation is the addition of a water volume equivalent to 2.0-2.5 times the dry weight of the paper (Brasil, 2009, 2013).

\section{Conclusion}

The germination test with E. phaeotricha seeds should be conducted at $30^{\circ} \mathrm{C}$ on paper, moistened with a water volume equivalent to 2.2 times the dry weight of the paper, with initial and final counts at 6 and 14 days after sowing, respectively.

\section{Literature Cited}

Araújo, A. M. S.; Assis, L. C. da S. L. G.; Nogueira, N. W.; Freitas, R. M. O. de; Torres, S. B. Substrates and temperatures for the germination of seeds of Senegalia tenuifolia (L.) Britton \& Rose. Revista Caatinga, v.29, p.113-118, 2016. http://dx.doi. org/10.1590/1983-21252016v29n113rc

Barros, R. T. de; Martins, C. C.; Silva, G. Z.; Martins, D. Origin and temperature on the germination of beggartick seeds. Revista Brasileira de Engenharia Agrícola e Ambiental, v.21, p.448453, 2017. http://dx.doi.org/10.1590/1807-1929/agriambi. v21n7p448-453

Barrozo, L. M. da; Alves, E. U.; Silva, R. dos S.; Anjos Neto, A. P. dos; Santos Neta, M. das M. S. dos; Silva, B. F. da. Substratos e temperaturas para testes de germinação e vigor de sementes de Inga laurina (Sw.) Willd. Bioscience Journal, v.30, p.252-261, 2014. http://www.seer.ufu.br/index.php/biosciencejournal/article/ view/18037/14567

Brasil. Ministério da Agricultura, Pecuária e Abastecimento. Regras para Análise de Sementes. Brasília: MAPA/ACS, 2009. 395p.

Brasil. Ministério da Agricultura, Pecuária e Abastecimento. Instruções para análise de sementes de espécies florestais. Brasília: MAPA/ACS, 2013. 98p.

Cetnarski Filho, R.; Carvalho, R. I. N. de. Massa da amostra, substrato e temperatura para teste de germinação de sementes de Eucalyptus dunnii Maiden. Ciência Florestal, v.19, p.257-265, 2009. http://www.redalyc.org/html/534/53413082003/

Ferreira, M.; Simões, J. W.; Scanavaca Júnior, L.; Teles, P. E. dos S. Teste de populações de Eucalyptus phaeotricha Blakely \& Mckie em Anhembi, SP. Anhembi: Instituto de Pesquisa e Estudos Florestais, 1992. $18 \mathrm{p}$.

Gonçalves, E. P.; França, P. R. C. de; Viana, J. S.; Alves, E. U.; Guedes, R. S.; Lima, C. R. de. Umedecimento do substrato e temperatura na germinação de sementes de Parkia platycephala Benth. Ciência Florestal, v.25, p.563-569, 2015. http://www.redalyc.org/articulo. oa? $\mathrm{id}=53441497003$ 
Guedes, R. S.; Alves, E. U.; Gonçalves, E. P.; Braga Júnior, J. M.; Viana, J. S.; Colares, P. N. Q. Substratos e temperaturas para testes de germinação e vigor de sementes de Amburana cearensis (Allemão) A. C. Smith. Revista Árvore, v.34, p.57-64, 2010. http://www.scielo. br/pdf/rarv/v34n1/v34n1a07

Labouriau, L. G.; Valadares, M. E. B. On the germination of seeds Calotropis procera (Ait.) Ait.f. Anais da Academia Brasileira de Ciências, v.48, p.263-284, 1976.

Lorenzi, H. Árvores exóticas no Brasil. 1.ed. Nova Odessa: Instituto Plantarum, 2003. 382p.

Maguire, J. D. Speed of germination-aid in selection and evaluation for seedlings emergence and vigor. Crop Science, v.2, p.176-177, 1962.

Martins, C. C.; Martinelli-Selene, A.; Nakagawa, J. Estágio de colheita e substrato para o teste de germinação de sementes de ipê (Tabebuia chrysotricha (Mart. ex DC.) Standl.). Revista Árvore, v.32, p.27-32, 2008. http://www.redalyc.org/html/488/48813376004/

Martins, C. C.; Pereira, M. R. R.; Lopes, M. T. G. Germinação de sementes de eucalipto sob estresse hídrico e salino. Bioscience Journal, v.3, p.318-329, 2014. http://www.seer.ufu.br/index.php/ biosciencejournal/article/view/18058/14543

Martins, C. C.; Pereira, M. R. R.; Marchi, S. R. Germinação de sementes de Melaleuca quinquenervia em condições de estresse hídrico e salino. Planta Daninha, v.29, p.1-6, 2011.
Nogueira, F. C. B.; Gallão, M. I.; Bezerra, A. M. E.; Medeiros Filho, S. Efeito da temperatura e luz na germinação de sementes de Dalbergia cearensis Ducke. Ciência Florestal, v.24, p.995-1005, 2014. http://www.redalyc.org/html/534/53432889019/

Silva, R. B. e; Matos, V. P.; Farias, S. G. G. de; Sena, L. H. de M.; Silva, D. Y. B. de O. Germinação e vigor de plântulas de Parkia platycephala Benth. em diferentes substratos e temperaturas. Revista Ciência Agronômica, v.48, p.142-150, 2017. http://dx.doi. org/10.5935/1806-6690.20170016

Sousa, F. H. M.; Patriota, J. N.; Ferreira Júnior, D. F.; Oliveira, L. M.; Souza, P. B. Umedecimento do substrato, temperatura na germinação e vigor de sementes de Bixa orellana L. Revista Verde de Agroecologia e Desenvolvimento Sustentável, v.10, p.199-205, 2015. http://dx.doi.org/10.18378/rvads.v10i2.2947

Tomaz, C. A.; Martins, C. C.; Silva, G. Z. da; Vieira, R. D. Period of time taken by Brachiaria humidicola (Rendle) Scheweick seed to complete germination. Revista Semina: Ciências Agrárias, v.37, p.693-700, 2016. http://dx.doi.org/10.5433/1679$0359.2016 \mathrm{v} 37 \mathrm{n} 2 \mathrm{p} 693$

Varela, V. P.; Ramos, M. B. P.; Melo, M. de F. F. Umedecimento do substrato e temperatura na germinação de sementes de angelimpedra (Dinizia excelsa Ducke). Revista Brasileira de Sementes, v.27, p.130-135, 2005. 